\title{
Does Female Representation in Top Management Improve Firm Performance? A Panel Data Investigation
}

\author{
Cristian L. Dezső \\ University of Maryland \\ Robert H. Smith School of Business \\ 3347 Van Munching Hall \\ College Park, MD 20742 \\ 301-405-7832 \\ cdezso@rhsmith.umd.edu \\ David Gaddis Ross \\ Columbia Business School \\ Uris Hall, Room 726 \\ New York, NY 10027 \\ 212-854-5606 \\ dr2175@columbia.edu
}

Keywords: gender, top management teams, firm performance, innovation

This is the pre-peer-reviewed version of the article published in final form at Strategic Management Journal 33, no. 9 (September 2012): 1072-1089. 


\title{
Does Female Representation in Top Management Improve Firm Performance? A Panel Data Investigation
}

\begin{abstract}
We argue that female representation in top management brings informational and social diversity benefits to the top management team, enriches the behaviors exhibited by managers throughout the firm, and motivates women in middle management. The result should be improved managerial task performance and thus better firm performance. We test our theory using 15 years of panel data on the top management teams of the S\&P 1,500 firms. We find that female representation in top management improves firm performance but only to the extent that a firm's strategy is focused on innovation, in which context the informational and social benefits of gender diversity and the behaviors associated with women in management are likely to be especially important for managerial task performance.
\end{abstract}


For the past decades, women have made considerable inroads into domains traditionally dominated by men. However, even though women now account for over a third of U.S. managers overall (Bureau of Labor Statistics, 2007), women remain significantly underrepresented at the top of the corporate hierarchy, both in the boardroom (Hillman, Shropshire, and Cannella Jr., 2007) and in top management (Daily, Certo, and Dalton, 1999; Helfat, Harris, and Wolfson, 2006). For instance, in 2006, among the corporations included in the Standard \& Poor's (S\&P) 1,500 index, which is designed to reflect the overall U.S. equity market, ${ }^{1}$ only 30 percent had even a single woman among their top managers, and this figure has stagnated in recent years. See Figure 1.

Insert Figure 1 about Here

Beyond the social and ethical implications, the dearth of women at the top of the corporate hierarchy suggests that female representation in top management may have important implications for a firm's competitiveness, not merely as a reflection of a more gender neutral and thus more meritocratic recruitment and promotion process, but more specifically because of the potential benefits of gender diversity itself. With this in mind, this paper asks the following questions: Does female representation in top management have a positive effect on firm performance? If so, is the effect general or confined to particular contexts?

\footnotetext{
${ }^{1}$ The S\&P 1,500 combines the S\&P 500 (large capitalization stocks), the S\&P MidCap 400, and the S\&P SmallCap 600 to cover approximately $90 \%$ of U.S. market capitalization. It is designed for investors seeking to replicate the performance of the U.S. equity market or benchmark against a representative universe of tradable stocks (Standard \& Poor's, 2010).
} 
In addressing these questions, the paper makes two distinct but related contributions. Our first contribution is to draw on a range of management literatures to craft a theoretical model to explain how female representation in top management brings informational and social diversity benefits to the top management team, enriches the behaviors exhibited by managers throughout the firm, and motivates women in middle management. In consequence, we argue that female representation in top management improves managerial task performance throughout the firm and should accordingly lead to better firm performance, even for a firm that has hypothetically eliminated barriers to managerial advancement by women.

Given the importance of identifying moderating contextual factors for both research and practice vis-à-vis organization theory (Lawrence and Lorsch, 1967), upper echelons (Carpenter, Geletkanycz, and Sanders, 2004), and gender in organizations (Butterfield and Grinnell, 1999), an important aspect of our model is to theorize about how strategically relevant organizational contexts moderate the impact of female representation in top management. In that connection, our theoretical model predicts that the positive impact of female representation in top management on firm performance is increasing in a firm's innovation intensity, in which context the improvements in group decision-making associated with gender diversity and the managerial attributes of women managers themselves are likely to be especially important. We find, in fact, that innovation intensity does not merely positively moderate the effect of female representation in top management on firm performance but that female representation in top management benefits firm performance only to the extent that a firm's strategy is focused on innovation. 
Our second contribution has both theoretical and empirical dimensions. Terjesen, Sealy, and Singh (2009) point out in a recent comprehensive survey that existing empirical work on the relationship between female representation at the top of the corporate hierarchy and firm performance (the vast majority of which studies corporate boards) has produced decidedly mixed results and, more importantly, does not address the related issues of causality and endogeneity. Contrast, for instance, Lee and James's (2007) well-known finding that hiring a woman $\mathrm{CEO}$ is associated with a negative stock price reaction, with Carter, Simpkins, and Simpson's (2003) result that gender diversity on boards is associated with better firm performance.

Likewise, a small number of pioneering studies draw on the resourced-based view (Shrader, Blackburn, and Iles, 1997), cultural diversity (Richard, Barnett, Dwyer, and Chadwick, 2004), and social identity and power sharing (Krishnan and Park, 2005) literatures to theorize about and empirically study the relationship between female representation at various levels of management and firm performance; yet, each of these studies finds no or inconsistent evidence for such a relationship. In addition, constrained by data limitations, these studies do not control for many observable factors that might influence firm performance (e.g., leverage or firm age), and, more importantly, fail to account for (a) the unobservable heterogeneity associated with particular firms or time periods that might simultaneously affect the level of female representation in top management and firm performance and (b) the related possibility of reverse causality.

In fact, as discussed further below, there exist a range of reasons for expecting that $a$ priori better firms are more likely to promote women to their top management teams. As 
with other aspects of the management of human assets, then, a full picture of the causal linkages between female representation in top management and firm performance 'can best be assessed by evaluating firms' longitudinal financial performance' (Chadwick and Dabu, 2009: 269). We are able to evaluate these causal linkages, because the richness of the panel data we compiled from a variety of public and private sources on the S\&P 1,500 U.S. corporations over a 15 -year period allows us to control for a wide array of firm and time specific observable and unobservable factors that may affect firm performance, as well as address the possibility of reverse causality. We are consequently able to provide a significantly more robust analysis of the potential benefits of female representation in top management and the contingencies that moderate these potential benefits than prior work in this area.

\section{THEORETICAL FRAMEWORK}

Figure 2 outlines our theoretical model for how female representation in top management may improve the performance of a firm, even a firm that has a hypothetically gender neutral recruitment and promotion process. We elaborate on our theoretical model below.

Insert Figure 2 about Here

\section{Top Management Team Task Performance}

A firm's behavior and performance are to a large extent a function of its top management team, which makes most of the firm's important strategic and organizational decisions 
(Hambrick and Mason, 1984; Carpenter et al., 2004). Anything that improves the task performance of the top management team should accordingly improve firm performance.

As shown in Figure 1, top management teams are overwhelmingly composed of men. Accordingly, when a woman joins a firm's top management team, the team becomes more diverse, both in terms of social categorization and information (Van Knippenberg, De Dreu, and Homan, 2004). There are a number of distinct but related reasons why this diversity should improve the information processing and decision-making of the team. Clearly, women add to the diversity of life experiences among a top management team's members. Women may thus have additional insight into important strategic questions, especially those that relate to female consumers, employees, and trading partners (Daily, Certo, and Dalton, 1999). In general, more heterogeneous groups have different points of view and knowledge, consider a more comprehensive set of solutions, and debate each others' viewpoints more vigorously, leading to higher quality decisions (Hoffman and Maier, 1961; Wiersema and Bantel, 1992), especially where, as with top management team decision-making, the group task has a high information-processing component (Van Knippenberg et al., 2004).

Moreover, gender is salient and readily accessible for social categorization (Tsui, Egan, and O'Reilly III, 1991; Westphal and Milton, 2000). Such surface-level diversity can trigger expectations that informational differences may be present and legitimize the expression of divergent perspectives among the male majority even if the surface-level diversity is not in fact associated with greater information diversity (Phillips and Loyd, 2006; Phillips, Liljenquist, and Loyd, 2009). It follows that even the presence of a woman 
with congruent information may stimulate a broader and richer discussion of alternatives and thus improve decision-making within the top management team.

While diversity may become excessive, causing problems with communication (Wiersema and Bantel, 1992), this concern is unlikely to be empirically relevant for most top management teams, because the number of teams with more than a small minority of women is vanishingly small. Diversity may also negatively impact social cohesion and thus employee satisfaction (Tsui et al., 1991). However, affective discomfort does not necessarily imply inferior performance; indeed, research suggests that the affective discomfort associated with diversity is intimately related to the superior decision-making to which diversity can give rise (e.g., Phillips et al., 2009). Intuitively, some level of conflict, dissent, and cognitive cost may often accompany the full elaboration of alternative perspectives that leads to better decision-making in diverse groups (Van Knippenberg et al., 2004). Researchers have argued that because of the non-routine nature of the problems faced by corporate boards, the benefits of gender diversity outweigh the costs (Hillman et al., 2007). These arguments should if anything be more applicable to top management teams, whose remit is by definition more specifically tied to managerial problem solving than corporate boards, which primarily act as monitors and sources of information (Hillman and Dalziel, 2003).

Finally, a large body of field and laboratory work suggests that there may be genderbased differences in managerial behavioral tendencies. Based on surveys and interviews with female leaders, Rosener (1995) finds that women exhibit an interactive leadership style that emphasizes inclusion. Specifically, women are said to encourage participation 
by soliciting input from others, share power and information by keeping open communication channels with their subordinates, and bolster their subordinates' sense of self-worth. Using similar methods, other authors find women to be less hierarchical and more cooperative and collaborative than men (Helgesen, 1990; Book, 2000). Likewise, meta-analytic investigations reveal that, in organizational settings, women tend to manage in a more democratic and participatory way (Eagly and Johnson, 1990). These behaviors, which we collectively call the 'feminine management style,' are conveyed colloquially by Michael Landel, CEO of Sodexo: 'Women like power, but they like to share it. They like to be more collaborative' (Womenomics, 2009). Such managerial behaviors promote the sharing of task-relevant information (Daily and Dalton, 2003), a key process underlying the positive effects of diversity (Van Knippenberg et al., 2004).

We accordingly expect gender diversity, especially in the form of adding a woman to an otherwise all-male top management team, to improve the team's task performance. Better task performance by the top management team in turn leads directly to better firm performance.

\section{Middle Management Task Performance}

We also expect female representation in top management to have positive reverberations throughout a firm's management hierarchy for a number of reasons. Career progression through a firm's managerial ranks may be likened to a succession of competitions, each of which has implications for a manager's subsequent upward mobility (Rosenbaum, 1979). Appropriate mentoring relationships and other social contacts are important in this process. Social relationships are heavily influenced and constrained by similarity on 
social attributes, which notably include gender. The paucity of women in the upper echelons of management thus creates a significant barrier to managerial advancement by women (Noe, 1988; Ibarra, 1993), reducing their opportunity to acquire the experience that is important for their own advancement, for example, by working in management trainee programs (Sheridan, Slocum Jr., Buda, and Thompson, 1990) or in corporate office positions, which may be especially valuable for women (Hurley and Sonnenfeld, 1998). Conversely, where women do occupy senior managerial positions, they have been found to focus more than men on the development and mentoring of their subordinates, encouraging them to reach their full potential and rewarding them for good performance (Eagly, Johannesen-Schmidt, and van Engen, 2003).

Thus, a woman has good reason to believe that the presence of women in top management positions is a critical factor for her likely success at the firm and adjust her commitment and motivation accordingly. Indeed, researchers have argued that the presence of a woman on the corporate board indicates that, whatever barriers to advancement by women may exist in society, the culture of the firm is friendly to women and committed to the advancement of women at all levels (Bilimoria, 2000, 2006; Daily and Dalton, 2003), enhancing the motivation and organizational commitment of women in lower-level managerial positions. Given that the members of the top management team are more likely than board members to have been recruited from within the firm, we would expect the positive impact of female representation in top management on the motivation of lower-level women managers to be stronger than the effect of female board representation. It follows that female representation in top management should engender greater motivation and organizational commitment in lower-level women managers, 
leading them to improve their individual performance and contributions to the managerial groups to which they belong.

In addition, women managers may face a problem of incongruity between expectations about the actual and ideal behavior of women and men on the one hand and the attributes typically associated with successful leaders on the other (Ely and Meyerson, 2000). Specifically, based on the descriptive aspect of the female gender role, women are deemed to possess inferior leadership abilities; when women fail to perform well on masculine aspects of competence, their failures are interpreted as confirming these stereotypes. Meanwhile, based on the injunctive aspect of the female gender role, women are evaluated less favorably or even denigrated when their behavior fulfills the prescriptions of the leadership role, because this violates the female gender role.

However, empirical evidence suggests that women experience this role conflict less and have a more positive view of their own gender in firms with greater sex-integration at senior levels of the management hierarchy (Ely, 1994, 1995). In addition, women (and possibly men) in sex-integrated firms are more apt to enact masculine or feminine behaviors according to the demands of the task, rather than in conformity with historical gender norms (Ely, 1995). ${ }^{2}$ It follows that women (and possibly men) in lower-level managerial positions may regard the presence of a woman on the firm's top management team as a signal that the managerial behaviors associated with the feminine management

\footnotetext{
${ }^{2}$ One lawyer interviewed by Ely (1995: 613) put the matter thus: 'Women bring something to an all male institution when you integrate it... I think that men, when they run in packs, tend to act like small boys. I think there's a lot of the pecking-order-establishing and one-ups-manship and bravado. And I think women reduce the need for that somewhat. It still exists, but I think one thing women do is that they allow the existing men who are above that to feel comfortable excusing themselves from it because the women do, by and large.'
} 
style described above are valued by the organization, effectively legitimizing the adoption of these behaviors by women (and possibly men) when doing so would improve individual and group task performance.

We accordingly expect that female representation in top management will not only improve the task performance of the top management team itself but also increase the motivation and commitment of women at lower managerial levels as well as encourage the adoption of behaviors associated with the feminine management style, as and when appropriate. Each of these effects should in turn improve individual and group task performance throughout the firm and thereby improve firm performance itself. We accordingly propose:

Hypothesis 1: Female representation in top management has a positive effect on firm performance.

\section{Strategic Context and the Benefits of Gender Diversity}

We expect the benefits of diversity to be context specific (Klein and Harrison, 2007). Gender diversity, by leading to more thorough information processing and consideration of divergent views, should be particularly valuable for tasks requiring creative solutions (Van Knippenberg et al., 2004), such as the process of innovation, which relies on the insightful and unique recombination and reapplication of existing resources (Schumpeter, 1934; Penrose, 1959). Diversity has in general been associated with high levels of creativity and innovation (Wiersema and Bantel, 1992), and Hoffman and Maier (1961) find that gender diversity in particular facilitates creativity. It follows that female 
representation in top management should be especially beneficial for firms for which innovation is important to strategy and thus is more relevant to the activities of managers throughout the firm (Ginsberg, 1994).

Differences in managerial behavior may also provide context specific benefits. In general, innovation leaves managers more latitude to make decisions, thereby amplifying the importance of managerial effectiveness for firm performance (Castanias and Helfat, 2001). Motivation is also a key contributor to creativity (Oldham and Cummings, 1996). The positive implications of female representation in top management for the motivation and organizational commitment of women managers at lower levels in the hierarchy should accordingly be particularly beneficial where these women managers are more heavily engaged in innovation-related tasks.

Supervisory behavior is another important influence on employee motivation. For example, 'informational verbal rewards' have been found to increase intrinsic motivation while 'controlling verbal rewards' do not (Pittman, Davey, Alafat, Wetherhill, and Kramer, 1980; Ryan, Mims, and Koestner, 1983). 'Supportive' managerial behaviors have been found to bolster feelings of self-determination and personal initiative and thereby increase intrinsic motivation, whereas controlling supervisory behaviors undermine intrinsic motivation (Oldham and Cummings, 1996). Research also finds that intrinsic motivation is bolstered by autonomy support, which leads to better conceptual learning, itself a contributor to creativity (Deci and Ryan, 1987). Lastly, empowering and participatory leadership styles have been linked to intrinsic motivation and creativity (Zhang and Bartol, 2010), as well as to more sharing of information in group discussions 
(Larson, Foster-Fishman, and Franz, 1998), which should lead to the generation of more ideas. It follows that innovation success is a product of 'bargaining and negotiation' to 'accumulate information' and 'coalition building,' not 'domination of others' (Kanter, $1983,1988) .^{3}$

Intriguingly, these more cooperative, nurturing, and collaborative managerial behaviors overlap considerably with the feminine management style as described above. To the extent that female representation in top management promotes such managerial behaviors, either as directly manifested by the women on the top management team or as a response by women (and possibly men) at lower levels of the firm's hierarchy to a less male-dominated work environment, we would expect female representation in top management to be particularly beneficial for firms for which innovation is important to strategy. These various arguments all imply the following hypothesis:

Hypothesis 2: The effect of female representation in top management on firm performance is positively moderated by innovation intensity.

\section{METHODS}

\section{Data and Variable Definitions}

Our source for the size and gender composition of top management teams is Standard \& Poor's (S\&P) ExecuComp database, which contains information on senior managers

\footnotetext{
${ }^{3}$ Experimental evidence supports this general proposition. In an R\&D context, for instance, both Andrews and Farris (1967) and Amabile (1988) find that 'freedom' for employees is positively associated with innovation. Oldham and Cummings (1996) obtain similar results among technical teams in manufacturing facilities. Scott and Bruce (1994) show that the degree to which interactions between a supervisor and subordinate are characterized by 'trust, mutual liking, and respect' is positively related to the subordinate's innovative behavior.
} 
from proxy statements and other public filings of the S\&P 1,500 firms, a widely used index of public companies designed to reflect the broad U.S. equity market (Standard \& Poor's, 2010); our sample covers the years 1992, the first year of the ExecuComp data, through 2006. Although the rules have changed modestly since 1992, in general, U.S. public companies have been and continue to be required to report information on the CEO and four other most highly-paid managers. We accordingly have information on at least five managers for the substantial majority of firm years in the data, and some firms report information for a small number of additional managers. We take the managers reported in ExecuComp to be a firm's top management team. At 5.9, the mean size of a top management team in our data is in line with studies in the upper echelons literature, which typically report the 'inner circle' of top management teams to number between three and seven people (Carpenter and Sanders, 2002). Our definition of the top management team is broader than that of the 'dominant coalition' of the early upper echelons literature, which typically included only managers who also serve on the board of directors (Carpenter et al., 2004).

We use S\&P's CompuStat database as a source of financial information about the firms in our sample. CompuStat collects financial information from firms' public filings. We use the Center for Research in Securities Prices (CSRP) as a source of firms' initial public trading date. CSRP provides stock trading information for firms whose shares trade on the NYSE, AMEX, and NASDAQ exchanges.

Female Representation. While, in principle, women could account for any percentage of the top management team of a given firm, (a) the fraction of firms with even a single 
woman on the top management team never reaches a third in any year and is usually substantially lower, and (b) the number of firms with more than one woman on the top management team never exceeds 8.5 percent. (See Figure 1.) We accordingly operationalize female representation in top management using a dummy variable, Female Representation, which takes the value $1(0)$ if any (none) of the managers reported in ExecuComp for a given firm in a given year is female. (We consider alternative measures of female representation in top management below.)

Firm Performance. While we consider accounting measures of performance in an extension to our basic analysis, our primary measure of firm performance is Tobin's Q, which is defined as the ratio of the market value of a firm's assets to their replacement value (Tobin, 1969). The idea is that better firms create more economic value from a given quantity of assets. Importantly, Tobin's Q is a forward-looking measure that captures the value of a firm as a whole rather than as the sum of its parts and implicitly includes the expected value of a firm's future cash flows, which are capitalized in the market value of a firm's assets (i.e., the combined market value of a firm's debt and equity). ${ }^{4}$ By contrast, accounting rates of return are backward-looking and, because of biases in their calculation, may diverge significantly from true economic rates of return (Benston, 1985). Moreover, accounting numbers may be distorted by differences in risk, tax laws, and latitude in interpreting accounting regulations (Wernerfelt and Montgomery, 1988), as well as by earnings management (Healy and Wahlen, 1999). Tobin's Q implicitly uses the correct risk-adjusted discount rate, imputes equilibrium

\footnotetext{
${ }^{4}$ For these reasons, Tobin's $Q$ has long been favored as a measure of overall firm performance in management, economics, and finance. (See, for example, Lang and Stulz, 1994; Berger and Ofek, 1995; King and Lennox, 2001; and Durnev, Morck, and Yeung, 2004.)
} 
returns, and minimizes the distortion from tax laws and accounting conventions (Wernerfelt and Montgomery, 1988). We also note that investors, who ultimately determine the market value of a firm in the calculation of Tobin's Q, are increasingly focused on diversity as a driver of value; in fact, the SEC promulgated new rules requiring public firms to report board diversity from early 2010, largely in response to overwhelming demand from individual and institutional investors (Aguilar, 2009). ${ }^{5}$

We follow Bertrand and Schoar (2003) in calculating Tobin's Q: market value is the book value of a firm's assets plus the market value of the firm's common equity minus the book value of common equity and deferred taxes; replacement value is the book value of the firm's assets. We use a log transformation of Tobin's Q in our analysis to reduce skewness.

Innovation Intensity and Other Controls. We measure Innovation Intensity as the ratio of $\mathrm{R} \& \mathrm{D}$ expense to assets from the prior year and use it as a control in our analysis. We also use the interaction between Female Representation and Innovation Intensity to test Hypothesis 2. We use a broad set of additional control variables, many of which are commonly found in research on top management teams: (i) Size, as measured by book assets from the prior year; (ii) Firm Age (in years), with firm birth determined by the earlier of the firm's first year in CompuStat or CRSP; (iii) Leverage, or the ratio of debt to assets; (iv) CapEx Intensity, the ratio of capital expenditures to assets from the prior year; (v) Marketing Intensity, the ratio of advertising expense to assets from the prior

\footnotetext{
${ }^{5}$ Large investment funds that have campaigned publicly for greater gender diversity at the top of the corporate hierarchy include CalPERS, CalSTRS, and Pax World Funds, which sponsors the Global Women's Equality Fund, a mutual fund that focuses on investing in companies that promote gender equality and women's empowerment.
} 
year; (vi) Age of Capital Stock, which we measure indirectly as the ratio of depreciation expense to net property, plant, and equipment, since the book value of assets with a longer remaining useful life should be higher in relation to current depreciation expense; and (vii) the Number of Managers on the top management team reported in ExecuComp, as larger teams may be more likely to have a woman manager simply by dint of their size. (Size, Innovation Intensity, CapEx Intensity, Marketing Intensity, and Age of Capital Stock are log transformed to reduce skewness.) If R\&D expense or advertising expense is not material, a firm is not required to disclose it as a separate line item. Accordingly, if one of these items is not separately disclosed, we impute the value of zero to it.

\section{Statistical Analysis}

As noted, we test our hypotheses regarding the effect of female representation in top management on firm performance, while controlling for the many idiosyncratic and unobservable factors that may simultaneously affect a firm's performance and make the firm's work environment more or less congenial to women managers. The longitudinal nature of our data allows us to do this by including firm fixed effects in all of our regressions. By including a separate dummy variable for each firm, our statistical tests implicitly compare each firm with itself, i.e., when the firm has female representation in top management with when it does not, as well as for the industry in which a firm competes, since industries are composed of firms.

Figure 1 shows that female representation in top management increased steadily from 1992 until leveling off early in the 2000s. Social and economic trends over time may simultaneously affect firm performance and the propensity of firms to hire and promote 
senior women managers, for example, due to the diffusion of specific human resources practices that accommodate the personal commitments of women (Bloom, Kretschmer, and van Reenen, 2009). Again, we use the longitudinal nature of our data to control for these trends by including year fixed effects in all of our regressions.

\section{RESULTS}

Table 1 provides descriptive statistics for the variables used in the study, as well as their correlations. The low mean of Female Representation reflects the large number of firms without women in top management. The majority of firms are less than 30 years old, although a small number are significantly older.

Insert Table 1 about Here

Although most of the correlations are relatively small in magnitude, Female Representation does have a correlation of 0.32 with the interaction between Female Representation and Innovation Intensity. To ensure that this and other potential sources of collinearity are not affecting our results, we calculated variance inflation factors for these two variables and all of the controls described above. Female Representation and the interaction between Female Representation and Innovation Intensity had variance inflation factors of 1.20 and 1.50 , respectively, and none of the control variables had a variance inflation factor over 1.61. As these figures are well below Kutner and Nachtscheim's (2004: 409) suggested cutoff value of 10, we conclude that collinearity is not a significant issue in our analysis. 


\section{Base Case Analysis}

Table 2, Column 1 reports the results of a fixed effects regression of Tobin's Q on the control variables. All the controls are highly significant except for Marketing Intensity and Number of Managers. Size and Age of Capital Stock are negatively related to Tobin's Q, whereas Innovation Intensity and CapEx Intensity are positively related to Tobin's Q. In each case, the result can be explained by the positive association between Tobin's Q and growth opportunities (Lang, Ofek, and Stulz, 1996). Leverage has a negative association with Tobin's Q, as slow-growth cash rich firms have more capacity to make regular debt payments. Interestingly, Firm Age is positive and significant. This may be the converse of the 'liability of newness' (Stinchombe, 1965).

Hypothesis 1 predicts that firms with female representation in top management will enjoy superior performance. Table 2, Column 2 tests this proposition by adding Female Representation to the regression in Column 1. The coefficient on Female Representation is positive and statistically significant at the 5\% level, even in the presence of over 2,500 firm dummies to account for unobservable firm-level heterogeneity. This result provides indicative support for Hypothesis 1.

Insert Table 2 about Here

Female Representation is also economically significant. The coefficient on Female Representation of 0.0119 means that, ceteris paribus, Tobin's Q is approximately $1.19 \%$ 
higher with female representation in top management than without. ${ }^{6}$ More precisely, the mean value of book assets is $\$ 1.239$ billion while the mean of value of Tobin's $Q$ is $1.83,{ }^{7}$ implying a firm value of $\$ 2.263$ billion ( $\$ 1.239$ billion multiplied by 1.83 ). The coefficient on Female Representation of 0.0119 implies an increase in Tobin's Q to about $1.86^{8}$ and in firm value to $\$ 2.305$ billion ( $\$ 1.239$ billion multiplied by 1.86 ). Thus, female representation in top management leads to an increase of $\$ 42$ million in firm value at roughly the midpoint of the data.

\section{Innovation Intensity}

Hypothesis 2 predicts that Innovation Intensity will positively moderate the relationship between female representation in top management and firm performance. To test this, Column 3 adds the interaction between Female Representation and Innovation Intensity to the regression in Column 2. In Column 3, the coefficient on Female Representation represents the 'simple' effect of female representation in top management on firm performance, i.e., the effect when a firm's strategy is not at all related to innovation, because Innovation Intensity is zero (Jaccard and Turrisi, 2003; Echambadi and Hess, 2007); this coefficient is not statistically different from zero. In contrast, the coefficient on the interaction term is positive and highly statistically significant; thus, the more a

\footnotetext{
${ }^{6}$ Since the dependent variable, Tobin's Q, is log-transformed, the coefficients on the independent variables can be interpreted as representing approximate percentage changes in the underlying dependent variable.

${ }^{7}$ The figures are obtained after reversing the log transformation of the mean Size of 7.122 and mean Tobin's Q of 1.039 in Table 1.

${ }^{8}$ This figure is obtained after adding the effect of Female Representation to the mean of Tobin's Q, yielding 1.051 (1.039 plus 0.0119), and then reversing the log transformation.
} 
firm's strategy is focused on innovation, the more female representation in top management improves firm performance. ${ }^{9}$

This result strongly supports Hypothesis 2 and establishes an important boundary condition for the benefits of female representation in top management: While we find no evidence that female representation in top management may impair firm performance, in order for female representation in top management to have a positive impact on firm performance, the firm's strategy must be focused to some positive degree on innovation.

Again, the effects are economically significant. We demonstrate this by decomposing the simple and interaction effects for Female Representation and Innovation Intensity. The implied coefficient on Female Representation is equal to 0.3698 multiplied by the level of Innovation Intensity. Thus, if Innovation Intensity is zero, female representation in top management does not have a statistically significant effect on firm performance. However, at the mean level of Innovation Intensity of 0.034 , the implied coefficient on Female Representation is 0.0126 , implying an increase in firm value from female representation in top management of about $\$ 44$ million when calculated as above.

\footnotetext{
${ }^{9}$ If we mean-center Innovation Intensity, the sign and magnitude of the interaction between Female Representation and Innovation Intensity and the precision of the fit between the data and model are both identical. After mean-centering, the coefficient on Female Representation is larger, because it is a main effect, i.e., the effect of female representation in top management at the average value of Innovation Intensity. The main effect of Female Representation can be derived directly from the regression we report using a simple calculation (Echambadi and Hess, 2007). Because we consider the untransformed regression to have a more natural interpretation in this setting, we report regressions without mean-centering.
} 


\section{ROBUSTNESS AND EXTENSIONS}

\section{Alternative Measures of Female Representation in Top Management}

In our base case analysis, we measure female representation in top management using a dummy variable. Given that a small number of firms in our sample have more than one woman on the top management team, we redefine Female Representation as the percentage of a firm's top management team accounted for by women, and repeat the regression from Table 2, Column 3. The first column in Table 3 presents an excerpt of the results, which are qualitatively unchanged. ${ }^{10}$

\section{Insert Table 3 about Here}

By its nature, the CEO position would seem to have unique leadership attributes. Indeed, Lee and James (2007) find that firms' stock prices react negatively to the appointment of a woman CEO but exhibit no reaction to the appointment of women to other senior positions. We accordingly redefine Female Representation to exclude women CEOs and repeat the regression from Table 2, Column 3, with an excerpt of the results in the second column of Table 3 . The results are again qualitatively unchanged.

\footnotetext{
${ }^{10}$ The coefficient on the interaction between Female Representation and Innovation Intensity of 1.6224 implies that adding a woman to a five-person top management team would increase Tobin's Q by $1.6224 * 20 \%=32.4 \%$. That implies an increase in firm value of approximately $\$ 39$ million when calculated as in the Results section above. Extrapolating this calculation should be done with caution, however, as very few top management teams in the data have a majority of women.
} 


\section{Alternative Measures of Firm Performance}

While we have focused on Tobin's Q as a performance measure, because it is forwardlooking and holistic, there may be some interest in the relationship between female representation in top management and accounting measures of firm performance. We accordingly repeat the analysis in Table 2, Column 3 using Return on Assets and Return on Equity as dependent variables and report an excerpt of the results in Table $4 .{ }^{11}$ In line with the base case analysis, the simple effect of Female Representation is insignificant, whereas the coefficient on the interaction between Female Representation and Innovation Intensity is positive and highly statistically significant. Thus, the performance implications of female representation in top management are reflected in firms' accounting data.

Insert Table 4 about Here

\section{Endogeneity and Reverse Causality}

While our theoretical model holds that female representation in top management improves firm performance, there are also rarely articulated but still valid theoretical reasons for believing that, conversely, improved firm performance may lead to female representation in top management. The scarcity of women with experience in senior managerial positions (Hillman, Cannella Jr., and Harris, 2002) may allow those women to self-select into more successful firms (Farrell and Hersch, 2005). More successful firms

\footnotetext{
${ }^{11}$ Return on Assets is defined as operating income over assets from the prior period, and Return on Equity is defined as income before extraordinary items over common equity from the prior period. As with Tobin's Q, we apply a log transformation to reduce skewness.
} 
may be more likely to respond to pressure to conform to the aspirational norm of gender diversity, because they have a greater need for legitimacy (Meyer and Rowan, 1977), or because they have greater latitude and excess resources to do so (Pfeffer and Salancik, 1978). These theoretical arguments suggest that Female Representation may endogenously depend on recent firm performance and thus that the positive association between female representation and firm performance may be driven by reverse causality. If so, then once we control for prior firm performance, the positive association between female representation and firm performance should disappear.

Accordingly, as a robustness check, we add the lagged value of Tobin's Q to the regression in Table 2, Column 3 and report the results in Table 5, Column 1. Even in this demanding specification, we obtain qualitatively similar results. While the lagged value of Tobin's $\mathrm{Q}$ is positive and significant, as expected, the simple effect of Female Representation is not significant, and the interaction between Female Representation and Innovation Intensity is positive and highly statistically significant.

Insert Table 5 about Here

Adding the lagged value of the dependent variable to a panel data regression can give rise to problems with autocorrelation. Moreover, the other control variables associated with firm policies may also be endogenous. Arellano and Bond (1991) propose a dynamic panel Generalized Method of Moments (GMM) estimator to account for these issues. We 
accordingly repeat the analysis in Table 5, Column 1 in Column 2 using their estimator. ${ }^{12}$ We obtain qualitatively the same result: The lagged value of Tobin's Q is positive and significant, the simple effect of Female Representation is not significant, and the interaction between Female Representation and Innovation Intensity is positive, highly statistically significant, and larger than in Column 1. Our results are thus robust to controlling for endogeneity and reverse causality.

\section{DISCUSSION AND CONCLUSION}

\section{Contributions}

In this paper, we develop a theoretical model to explain how and under what circumstances female representation in top management improves firm performance. We test our theory using 15 years of data on a large and comprehensive sample of public U.S. corporations and find that (a) female representation in top management leads to better firm performance but (b) only to the extent that a firm is focused on innovation as part of its strategy.

Gender diversity has been identified as representing a 'needed innovation' for top management research (Carpenter et al., 2004: 771), because it is salient and readily accessible for group categorization even without necessarily reflecting cognitive differences (Tsui et al., 1991; Westphal and Milton, 2000). By elaborating on the benefits associated with gender diversity and the contingencies under which these benefits are likely to be amplified, this paper not only contributes to our understanding of gender in

\footnotetext{
${ }^{12}$ The specification treats variables that could be influenced by firm policy in period $t$ as endogenous and those that are not in the control of the firm or are calculated exclusively with respect to $t-1$ values as exogenous.
} 
management, but also extends the literature on top management teams beyond the wellestablished fact that managerial demographics, broadly construed, matter for firm outcomes.

The paper's results also have important ramifications for policy and practice, in which context the persistent underrepresentation of women in the upper echelons of management has received significant attention. While arguments in favor of equality of opportunity have generally carried the day as an abstract principle, redressing the underrepresentation of women in management has been frustrated by the perception among many male managers that efforts to promote gender diversity are motivated, inter alia, by 'political correctness' or a goal of favoring women at the expense of men (Catalyst, 2009). Indeed, the very word 'diversity' provokes strong emotional reactions in many people (Milliken and Martins, 1996). To overcome such resistance, as well as to capture the attention of senior managers who may be sympathetic to gender equity but may also be extremely busy, making a compelling business case for diversity is critical (Catalyst, 2009; Conrad, 2009). However, while scholars have advanced many arguments extolling the benefits of gender diversity in top management, rigorous systematic evidence regarding how and in what circumstances female representation in top management improves firm performance has been lacking.

We address this gap in the literature using a rich panel dataset, which allows us to control for a wide range of observable and unobservable factors that influence firm performance, as well as for the possibility of reverse causality. In essence, our econometric specification compares each firm with itself, that is, when the firm has female 
representation in top management with when it does not. We find that, ceteris paribus, a given firm generates on average 1\% (or over $\$ 40$ million) more economic value with at least one woman on its top management team than without any women on its top management team and also enjoys superior accounting performance. Moreover, while the benefits of female representation in top management are increasing in the innovation intensity of a firm's strategy, even firms without any significant emphasis on innovation do not experience impaired performance as a result of female representation in top management. Thus, our results suggest that even CEOs who believe their firms have gender-neutral recruitment and promotion processes should ensure that their firms maintain at least some level of gender diversity in top management. We believe that these results make a powerful business case for gender diversity and suggest that a CEO who goes the extra mile to help women overcome barriers to their managerial advancement will often be rewarded with improvements in firm performance.

\section{Caveats and Directions for Future Research}

This study is not without limitations, many of which may indicate fruitful avenues for future research. While the empirical approach in this study has clear strengths, we nonetheless acknowledge that the small sample field studies employed in other research domains may offer a richer understanding of context than our large sample methods can. In particular, such studies may provide supporting anecdotal evidence regarding the mechanisms that we theorize are behind the benefits of female representation in top management for firm performance. We regard that work and ours as mutually complementary. It is only through a willingness to cross paradigmatic boundaries that we 
will gain the best appreciation of how to accommodate the needs of women managers as well as deepen our understanding of the contribution they can make to firm performance.

It could be argued that our results may be partly driven by a human capital advantage. Women managers face many barriers to their advancement including, but not limited to, overt discrimination (Oakley, 2000) and social pressure leading to unintentional discrimination by colleagues (Altonji and Blank, 1999). Some firms may have unobservable attributes like cultures (Barney, 1986) or routines (Nelson and Winter, 1982) that reduce these barriers, leading to a sustained human capital advantage (Coff, 1997) from a superior manifestation of female managerial talent and thus to a higher quality managerial workforce overall. Women may also need to be 'that much better' to overcome barriers to their advancement, implying that senior women managers are of higher average quality than their male counterparts. Finally, effective management of human assets is a key success factor for innovative high technology firms (Banerjee and Campbell, 2009), and human assets are one of the most coveted resources and a key objective of acquirers in technical industries (Ranft and Lord, 2000, 2002). So, a human capital advantage may be more important in those contexts.

However, these arguments relate primarily on differences among firms. To wit, firms where one is more likely to observe women on the top management team are precisely those where the barriers to women's advancement are lower and thus where the presence or absence of women on the top management team would be more likely to reflect random idiosyncratic factors than the quality of the managers composing the team. Therefore, any positive association between female representation in top management 
and firm performance that is driven by an advantage in the management of human capital should disappear in the empirical specification we use herein, which implicitly compares firms with themselves by including a separate fixed effect for each firm, in addition to a fixed effect for each year. By contrast, our theoretical model provides a comprehensive explanation for why a given firm, even one that has a hypothetically gender-neutral recruitment and promotion process, would benefit from female representation in top management.

There may be a similar explanation for why we find that a firm's strategy must be at least somewhat focused on innovation for female representation in top management to benefit firm performance. By including a separate fixed effect for each firm in our data, our empirical testing strategy creates a high hurdle for finding a statistically significant effect of female representation in top management. Firms where one is more likely to observe a woman on the top management team are also those that are more likely to have women at senior levels just below the top management team in years when there is no woman on the top management team. Female representation just below top management may provide these firms some of the benefits that we hypothesize arise from female representation in top management, reducing the power of our statistical tests. If so, then, the performance benefits from female representation in top management would be even larger than our analysis implies and could accrue even to firms for which innovation is not important to strategy.

It is also possible that there are countervailing aspects of gender diversity that reduce the benefits of female representation in top management. The full elaboration of alternative 
points of view and sources of information to which gender diversity in the top management team gives rise may actually be counterproductive for routine tasks (De Dreu and Weingart, 2003). In general, homogenous groups may perform slightly better on simple tasks, even though heterogeneous groups do better on difficult tasks (Hambrick and Mason, 1984; Bowers, Pharmer, and Salas, 2000). Tsui et al. (1992) find, moreover, that diversity in gender and race has deleterious effects on the psychological commitment, absenteeism, and intention to stay of men working in operating units, suggesting that gender diversity may reduce the overall motivation of male managers. Where innovation is not at all important to a firm's strategy and the functions of the top management team are accordingly highly routinized, these potential negative effects of gender diversity may be sufficient to offset the benefits we hypothesized.

There is likewise ample scope for future research to consider other factors that may moderate the impact of female representation in top management on firm performance. For instance, the alternative perspectives of senior women managers may be especially valuable for firms that have a disproportionately large number of female customers. The size, structure, and composition of a firm's workforce may also influence the effect of female representation in top management, although the direction of the influence is not clear. On the one hand, the enhanced motivation of women managers engendered by female representation in top management may be especially beneficial for firms with a large percentage of women managers at lower levels in the hierarchy; on the other hand, firms without a large percentage of women at lower levels may benefit from hiring senior women managers to assist in recruiting women to lower levels. Similarly, while senior managers may have a greater relative effect in firms with smaller workforces, the nature 
of the senior manager's job and the degree to which women are underrepresented in senior management may also differ with the size of a firm's workforce. The degree to which innovation activities are distributed throughout a firm's organizational structure rather than being compartmentalized into specialized units may also affect the degree to which a firm's focus on innovation moderates the impact of female representation in top management.

Lastly, there is reason to believe that the results of this study may vary in other places and settings. To wit, research suggests that new practices are initially adopted by firms seeking to benefit from the overt purpose of these practices but that later adopters are more interested in gaining legitimacy (Zucker, 1983; Westphal and Zajac, 1994). It is also possible that as a younger generation of managers rises to the top of the corporate world, the effects of female representation on firm performance may change. It would therefore be interesting to examine whether the benefits of female representation in top management will persist if, at some future time, there is greater gender equality in the upper echelons of U.S. corporations. These and other questions suggest the need for more research on gender and management. 


\section{REFERENCES}

Aguilar LA. 2009. Speech by SEC Commissioner: Diversity in the Boardroom Yields Dividends. http://www.sec.gov/news/speech/2009/spch091009laa.htm (28 February 2011).

Altonji JG, Blank RM. 1999. Race and Gender in the Labor Market. In Handbook of Labor Economics 3c, Ashenfelter O, Card D (eds.). Amsterdam: North Holland: 31433259 .

Amabile TM. 1988. A Model of Creativity and Innovation in Organizations. In Research in Organizational Behavior 10, Staw BM, Cummings LL (eds.). JAI Press: 123-167.

Andrews FM, Farris GF. 1967. Supervisory Practices and Innovation in Scientific Teams. Personnel Psychology 20 (4): 497-515.

Arellano M, Bond S. 1991. Some Tests of Specification for Panel Data: Monte Carlo Evidence and an Application to Employment Equations. Review of Economic Studies 58 (2) 277-297.

Banerjee PM, Campbell BA. 2009. Inventor Bricolage and Firm Technology Research and Development. $R \& D$ Management 39 (5): 473-487.

Barney JB. 1986. Organizational Culture: Can It Be a Source of Sustained Competitive Advantage? Academy of Management Review 11 (3): 656-665.

Benston GJ. 1985. The Validity of Profits-Structure Studies with Particular Reference to the FTC's Line of Business Data. American Economic Review 75 (1): 37-67.

Berger PG, Ofek E. 1995. Diversification's Effect on Firm Value. Journal of Financial Economics 37 (1): 39-65.

Bertrand M, Schoar A. 2003. Managing with Style: The Effect of Managers on Firm Policies. Quarterly Journal of Economics 118 (4): 1169-1208.

Bilimoria D. 2000. Building the Business Case for Women Corporate Directors. In Women on Corporate Boards of Directors: International Challenges and Opportunities, Burke RJ, Mattis, MC (eds.). Dordrecths, The Netherlands: Kluwer Academic Publishers.

Bilimoria D. 2006. The Relationship between Women Corporate Directors and Women Corporate Officers. Journal of Managerial Issues 18 (1): 47-61.

Bloom N, Kretschmer T, Van Reenen J. 2009. Work-Life Balance, Management Practices and Productivity. In International Differences in the Business Practice and Productivity of Firms, Freeman R, Shaw K (eds.). forthcoming. Chicago, IL: University of Chicago Press. 
Book EW. 2000. Why the Best Man for the Job Is a Woman: The Unique Qualities of Leadership. New York, NY: HarperCollins.

Bowers C, Pharmer JA, Salas E. 2000. When Member Homogeneity Is Needed in Work Teams: A Meta-Analysis. Small Group Research 31 (3): 305-327.

Bureau of Labor and Statistics. 2007. Women in the Labor Force: A Databook.

Butterfield DA, Grinnell JP. 1999. "Re-Viewing" Gender, Leadership, and Managerial Behavior: Do Three Decades of Research Tell Us Anything? In Handbook of Gender \& Work, Powell GN (ed.). Thousand Oaks, CA: Sage Publications.

Carpenter MA, Geletkanycz MA, Sanders WG. 2004. Upper Echelons Research Revisited: Antecedents, Elements, and Consequences of Top Management Team Composition. Journal of Management 30 (6): 749-778.

Carpenter MA, Sanders WG. 2002. Top Management Team Compensation: The Missing Link Between CEO Pay and Firm Performance. Strategic Management Journal 23 (4): 367-375.

Carter DA, Simkins BJ, Simpson WG. 2003. Corporate Governance, Board Diversity, and Firm Value. Financial Review 38 (1): 33-53.

Castanias RP, Helfat CE. 2001. The Managerial Rents Model: Theory and Empirical Analysis. Journal of Management 27 (6): 661-678.

Catalyst. 2009. Workplace Diversity: How to Tackle Resistance. http://www.womensmedia.com/lead/119-workplace-diversity-how-to-tackleresistance.html (27 February 2011).

Chadwick C, Dabu A. 2009. Human Resources, Human Resource Management, and the Competitive Advantage of Firms: Toward a More Comprehensive Model of Causal Linkages. Organization Science 20 (1): 253-272.

Coff RW. 1997. Human Assets and Management Dilemmas: Coping with Hazards on the Road to Resource-Based Theory. Academy of Management Review 22 (2): 374-402.

Conrad J. 2009. Don't Derail Your Diversity Training: Seven Common Traps to Avoid when Conducting Diversity Training. Employee Benefit News 23 (1): 15-16.

Daily CM, Certo TS, Dalton DR. 1999. A Decade of Corporate Women: Some Progress in the Boardroom, None in the Executive Suite. Strategic Management Journal 20 (1): 93-99.

Daily CM, Dalton DR. 2003. Women in the Boardroom: A Business Imperative. Journal of Business Strategy 24 (5): 8-9. 
Deci EL, Ryan RM. 1987. The Support of Autonomy and the Control of Behavior. Journal of Personality and Social Psychology 53 (6): 1024-1037.

De Dreu CKW, Weingart LR. 2003. Task and Relationship Conflict, Team Performance, and Team Member Satisfaction: A Meta-Analysis. Journal of Applied Psychology 88 (4): 741-749.

Durnev A, Morck R, Yeung B. 2004. Value Enhancing Capital Budgeting and Firm Specific Stock Return Variation. Journal of Finance 59 (1): 65-105.

Eagly, AH, Johannesen-Schmidt MC, van Engen ML. 2003. Transformational, Transactional, and Laissez-Faire Leadership Styles: A Meta-Analysis Comparing Women and Men. Psychological Bulletin 129 (4): 569-591.

Eagly AH, Johnson BT. 1990. Gender and Leadership style: A Meta-Analysis.

Psychological Bulletin 108 (2): 233-256.

Echambadi R, Hess JD. 2007. Mean-Centering Does Not Alleviate Collinearity Problems in Moderated Multiple Regression Models. Marketing Science 26 (3): 438-445.

Ely RJ. 1994. The Effects of Organizational Demographics and Social Identity on Relationships among Professional Women. Administrative Science Quarterly 39 (2): 203238.

Ely RJ. 1995. The Power in Demography: Women's Social Construction of Gender Identity at Work. Academy of Management Journal 38 (3): 589-634.

Ely RJ, Meyerson DE. 2000. Theories of Gender in Organizations: A New Approach to Organizational Analysis and Change. In Research in Organizational Behavior 22B, Staw M, Sutton RI (eds.). New York, NY: Elsevier/JAI: 103-151.

Farrell KA, Hersch PL. 2005. Additions to Corporate Boards: The Effect of Gender. Journal of Corporate Finance 11 (1-2): 85-106.

Finkelstein S., Hambrick DC. 1996. Strategic Leadership: Top Executives and Their Effects on Organizations. St. Paul, MN: West Publishing Company.

Ginsberg A. 1994. Minding the Competition: From Mapping to Mastery. Strategic

Management Journal 15: Special Issue: Competitive Organizational Behavior: 153-174.

Hambrick DC, Mason PA. 1984. Upper Echelons: The Organization as a Reflection of Its Top Managers. Academy of Management Review 9 (2): 193-206.

Healy PM, Wahlen JM. 1999. A Review of the Earnings Management Literature and Its Implications for Standard Setting. Accounting Horizons 13 (4): 365-383.

Helfat CE, Harris D, Wolfson PJ. 2006. Women and Men in the Top Executive Ranks of U.S. Corporations. Academy of Management Perspectives 20 (4): 42-64. 
Helgesen S. 1990. The Female Advantage: Women's Way of Leadership. New York, NY: Doubleday.

Hillman AJ, Cannella Jr AA, Harris IC. 2002. Women and Racial Minorities in the Boardroom: How Do Directors Differ? Journal of Management 28 (6): 747-763.

Hillman AJ, Dalziel T. 2003. Boards of Directors and Firm Performance: Integrating Agency and Resource Dependence Perspectives. Academy of Management Review 28 (3): 383-396.

Hillman AJ, Shropshire C, Cannella Jr AA. 2007. Organizational Predictors of Women on Corporate Boards. Strategic Management Journal 50 (4): 941-952.

Hoffman RL, Maier NRF. 1961. Quality and Acceptance of Problem Solutions by Members of Homogenous and Heterogeneous Groups. Journal of Abnormal and Social Psychology 62 (2): 401-407.

Hurley AE, Sonnenfeld JA. 1998. The Effect of Organizational Experience on Managerial Career Attainment in an Internal Labor Market. Journal of Vocational Behavior 52: 172-190.

Ibarra H. 1993. Personal Networks of Women and Minorities in Management: A Conceptual Framework. Academy of Management Review 18 (1): 56-87.

Jaccard J, Turrisi R. 2003. Interaction Effects in Multiple Regression. Thousand Oaks, CA: Sage Publications.

Kanter RM. 1983. The Change Masters. New York, NY: Simon and Schuster.

Kanter RM. 1988. When a Thousand Flowers Bloom: Structural, Collective, and Social Conditions for Innovation in Organization. In Research in Organizational Behavior 10B, Staw M, Cummings LL (eds.). JAI Press: 169-211.

King A, Lennox M. 2001. Exploring the Locus of Profitable Pollution Reduction. Management Science 48 (2): 698-716.

Klein KJ, Harrison DA. 2007. On the Diversity of Diversity: Tidy Logic, Messier Realities. Academy of Management Perspectives 21 (4): 26-33.

Krishnan HA, Park D. 2005. A Few Good Women - On Top Management Teams. Journal of Business Research 58 (12): 1712-1720.

Kutner MH, Nachtsheim CJ. 2004. Applied Linear Regression Models. Boston, MA: McGraw-Hill/Irwin.

Lang L, Ofek E, Stulz RM. 1996. Leverage, Investment, and Firm Growth. Journal of Financial Economics 40 (1): 3-29. 
Lang LHP, Stulz RM. 1994. Tobin's Q, Corporate Diversification, and Financial Performance. Journal of Political Economy 102 (6): 1248-1280.

Larson JR, Foster-Fishman PG, Franz TM. 1998. Leadership Style and the Discussion of Shared and Unshared Information in Decision-Making Groups. Personality and Social Psychology Bulletin 24 (5): 482-495.

Lawrence PR, Lorsch JW. 1967. Organization and Environment: Managing Differentiation and Integration. Boston, MA: Harvard University Press.

Lee PM, James EH. 2007. She'-E-Os: Gender Effects and Investor Reactions to the Announcements of Top Executive Appointments. Strategic Management Journal 28 (3): 227-241.

Meyer JW, Rowan B. 1977. Institutionalized Organizations: Formal Structure as Myth and Ceremony Institutionalized Organizations: Formal Structure as Myth and Ceremony. American Journal of Sociology 83 (2): 340-363.

Milliken FJ, Martins LL. 1996. Searching for Common Threads: Understanding the Multiple Effects of Diversity in Organizational Groups. Academy of Management Review 21 (2): 402-433.

Nelson RR, Winter SG. 1982. An Evolutionary Theory of Economic Change. Cambridge MA: Bellknap Press.

Noe RA. 1988. Women and Mentoring: A Review and Research Agenda. Academy of Management Review 13 (1): 65-78.

Oakley JG. 2000. Gender-Base Barriers to Senior Management Positions: Understanding the Scarcity of Female CEO's. Journal of Business Ethics 27 (4): 321-334.

Oldham GR, Cummings A. 1996. Employee Creativity: Personal and Contextual Factors at Work. Academy of Management Journal 39 (3): 607-634.

Penrose ET. 1959. The Theory of the Growth of the Firm. New York, NY: John Wiley and Sons.

Pfeffer J, Salancik GR. 1978. The External Control of Organizations: A Resource Dependence Perspective. New York, NY: Harper \& Row Publishers.

Phillips KW, Liljenquist KA, Neale MA. 2009. Is the Pain Worth the Gain? The Advantages and Liabilities of Agreeing with Socially Distinct Newcomers. Personality and Social Psychology Bulletin 35 (3): 336-350.

Phillips KW, Loyd DL. 2006. When Surface and Deep-Level Diversity Collide: The Effects on Dissenting Group Members. Organizational Behavior and Human Decision Processes 99: 143-160. 
Pittman TS, Davey ME, Alafat KA, Wetherill KV, Kramer N. 1980. Informational versus Controlling Verbal Rewards. Personality and Social Psychology Bulletin 6 (2): 228-233.

Ranft AL, Lord MD. 2000. Acquiring New Knowledge: The Role of Retaining Human Capital in Acquisitions of High-Tech Firms. Journal of High Technology Management Research 11 (2): 295-319.

Ranft AL, Lord MD. 2002. Acquiring New Technologies and Capabilities: A Grounded Model of Acquisition Implementation. Organization Science 13 (4): 420-441.

Richard OC, Barnett T, Dwyer S, Chadwick K. 2004. Cultural Diversity in Management, Firm Performance, and the Moderating Role of Entrepreneurial Orientation Dimensions. Academy of Management Journal 47 (2): 255-266.

Rosenbaum JE. 1979. Tournament Mobility: Career Patterns in a Corporation. Administrative Science Quarterly 24: 220-241.

Rosener JB. 1995. America's Competitive Secret: Utilizing Women as a Management Strategy. New York, NY: Oxford University Press.

Ryan RM, Mims V, Koestner R. 1983. Relation of Reward Contingency and Interpersonal Context to Intrinsic Motivation: A Review and Test Using Cognitive Evaluation Theory. Journal of Personality and Social Psychology 45 (4): 736-750.

Schumpeter J. 1934. The Theory of Economic Development. Cambridge, MA: Harvard University Press. First published in German in 1919.

Scott SG, Bruce RA. 1994. Determinants of Innovative Behavior: A Path Model of Individual Innovation in the Workplace. Academy of Management Journal 37 (3): 580607.

Sheridan JE, Slocum Jr JW, Buda R, Thompson RC. 1990. Effects of Corporate Sponsorship and Departmental Power on Career Tournaments. Academy of Management Journal 33 (3) 578-602.

Shrader CB, Blackburn VB, Iles P. 1997. Women in Management and Firm Financial Performance: An Exploratory Study. Journal of Managerial Issues 9 (3): 355-372.

Stinchcombe AL. 1965. Organizations and Social Structure. In Handbook of Organizations, March JG (ed.). Chicago, IL: Rand-McNally: 153-193.

Standard \& Poor's. 2010. S\&P Composite 1500.

http://www.standardandpoors.com/indices/sp-composite-1500/en/us/?indexId=spusa-15-usduf--p-us---- (18 December 2010).

Terjesen S, Sealy R, Singh V. 2009. Women Directors on Corporate Boards: A Review and Research Agenda. Corporate Governance: An International Review 17 (3): 320-337. 
Tobin J. 1969. A General Equilibrium Approach to Monetary Theory. Journal of Money, Credit and Banking 1 (1): 15-29.

Tsui AS, Egan TD, O'Reilly III CA. 1991. Being Different: Relational Demography and Organizational Attachment. Administrative Science Quarterly 37 (4): 549-579.

Van Knippenberg D, De Dreu CKW, Homan AC. 2004. Work Group Diversity and Group Performance: An Integrative Model and Research Agenda. Journal of Applied Psychology 89 (6): 1008-1022.

Wernerfelt B, Montgomery CA. 1988. Tobin's Q and the Importance of Focus in Firm Performance. American Economic Review 78 (1): 246-250.

Westphal JD, Milton LP. 2000. How Experience and Network Ties Affect the Influence of Demographic Minorities on Corporate Boards. Administrative Science Quarterly 45 (2): 366-398.

Westpha JD, Zajac EJ. 1994. Substance and Symbolism in CEOs' Long-Term Incentive Plans. Administrative Science Quarterly 39 (3): 367-390.

Wiersema MF, Bantel KA. 1992. Top Management Team Demography and Corporate Strategic Change. Academy of Management Journal 35 (1): 91-121.

Womenomics. 2009. Transformational Change Driven from the Top. http://www.womenomics.com/537-0-michel-landel-ceo-sodexo.html (25 May 2009).

Zhang X, Bartol KM. 2010. Linking Empowering Leadership and Employee Creativity: The Influence of Psychological Empowerment, Intrinsic Motivation, and Creative Process Management. Academy of Management Journal 53 (1): 107-128.

Zucker LG. 1983. Organizations as Institutions. In Research in the Sociology of Organizations, Bacharach SB(ed.). Greenwich, CT: JAI Press: 1-42 
Figure 1

Female Representation in Top Management across Time

\section{S\&P 1,500 Firms}

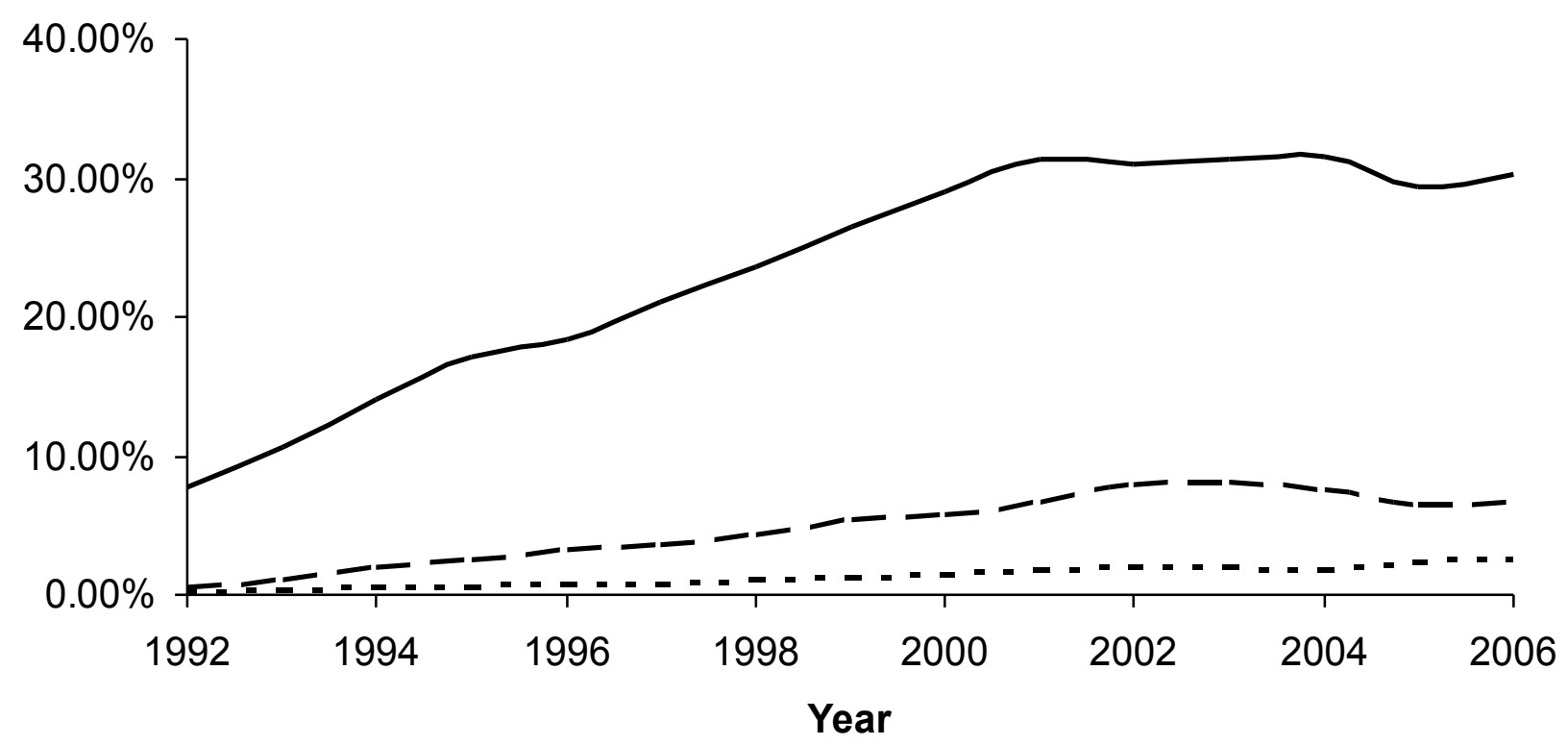

_ Firms with One or More Women on Top Management Team

_ - Firms with Two or More Women on Top Management Team

- - - - Firms with a Woman Chief Executive Officer

Source: ExecuComp. 
Figure 2

Theoretical Model

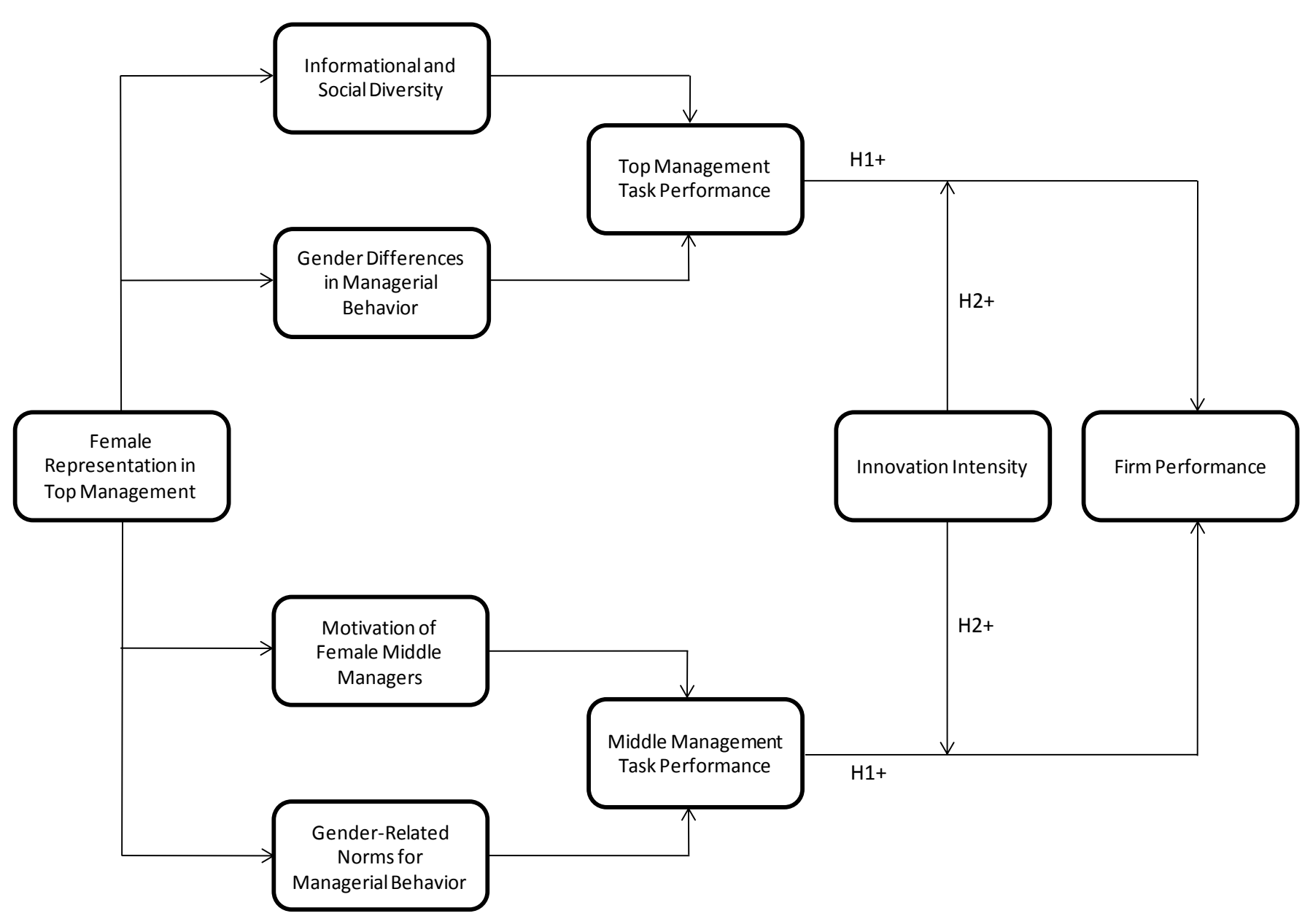


Table 1

Descriptive Statistics \& Correlations

\begin{tabular}{|c|c|c|c|c|c|c|c|c|c|c|c|c|c|c|}
\hline & Mean & S.D. & 1 & 2 & 3 & 4 & 5 & 6 & 7 & 8 & 9 & 10 & 11 & 12 \\
\hline 1. Female Representation & 0.236 & 0.425 & & & & & & & & & & & & \\
\hline 2. Innovation Intensity & 0.034 & 0.087 & 0.00 & & & & & & & & & & & \\
\hline 3. Size & 7.122 & 1.859 & 0.02 & -0.32 & & & & & & & & & & \\
\hline 4. Firm Age & 24.259 & 19.275 & -0.02 & -0.18 & 0.46 & & & & & & & & & \\
\hline 5. Leverage & 0.232 & 0.240 & -0.01 & -0.11 & 0.18 & 0.13 & & & & & & & & \\
\hline 6. CapEx Intensity & 0.071 & 0.099 & -0.02 & 0.22 & -0.22 & -0.12 & 0.00 & & & & & & & \\
\hline 7. Marketing Intensity & 0.013 & 0.047 & 0.04 & 0.12 & -0.11 & -0.03 & -0.04 & 0.13 & & & & & & \\
\hline 8. Age of Capital Stock & 0.203 & 0.191 & 0.04 & 0.23 & -0.17 & -0.23 & -0.12 & -0.15 & 0.03 & & & & & \\
\hline 9. Number of Managers & 5.930 & 1.435 & 0.13 & -0.02 & 0.22 & 0.18 & 0.05 & -0.04 & 0.00 & -0.03 & & & & \\
\hline 10. Tobin's Q & 1.039 & 0.390 & 0.05 & 0.42 & -0.34 & -0.23 & -0.19 & 0.18 & 0.15 & 0.13 & -0.08 & & & \\
\hline 11. Return on Assets & 0.095 & 0.157 & 0.00 & -0.36 & -0.02 & 0.00 & -0.11 & 0.00 & -0.03 & -0.17 & -0.04 & 0.22 & & \\
\hline 12. Return on Equity & 0.106 & 0.331 & 0.00 & -0.07 & 0.06 & 0.00 & -0.04 & 0.09 & 0.01 & -0.13 & -0.04 & 0.13 & 0.29 & \\
\hline $\begin{array}{l}\text { 13. Female Representation } x \\
\text { Innovation Intensity }\end{array}$ & 0.008 & 0.045 & 0.32 & 0.46 & -0.15 & -0.09 & -0.02 & 0.07 & 0.03 & 0.12 & 0.04 & 0.25 & -0.15 & -0.03 \\
\hline
\end{tabular}




\section{Table 2}

Female Representation in Top Management \& Firm Performance

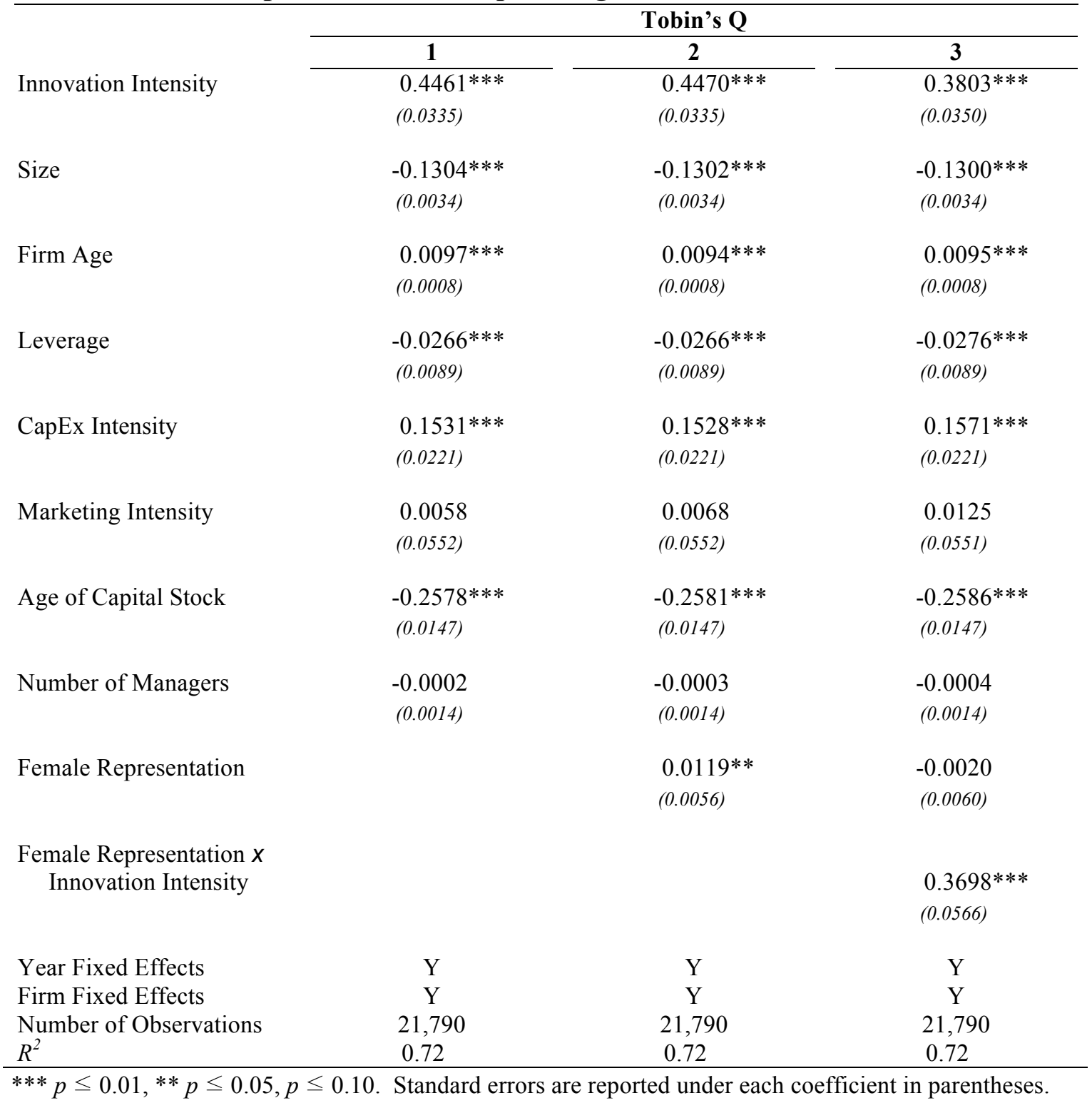




\section{Table 3}

Female Representation in Top Management \& Firm Performance Alternative Measures of Female Representation

\begin{tabular}{lcc}
\hline & \multicolumn{2}{c}{ Measure } \\
\cline { 2 - 3 } & $\begin{array}{c}\text { \%of Women on Top } \\
\text { Management Team }\end{array}$ & $\begin{array}{c}\text { Dummy Variable } \\
\text { Excluding Female CEOs }\end{array}$ \\
\cline { 2 - 3 } Female Representation & -0.0092 & -0.0004 \\
& $(0.0276)$ & $(0.0060)$ \\
Female Representation $x$ & $1.6224 * * *$ & $0.3670 * * *$ \\
Innovation Intensity & $(0.2706)$ & $(0.0569)$ \\
\hline$* * * p \leq 0.01, * * p \leq 0.05, p \leq 0.10$. & Standard errors are reported under each coefficient in parentheses.
\end{tabular}


Table 4

Female Representation in Top Management \& Firm Performance Accounting Measures of Firm Performance

\begin{tabular}{lcc}
\hline & \multicolumn{2}{c}{ Measure } \\
\cline { 2 - 3 } Female Representation & -0.0043 & Return on Equity \\
\cline { 2 - 3 } & $(0.0027)$ & -0.0059 \\
& & $(0.0081)$ \\
Female Representation $x$ & $0.1592 * * *$ & $0.2585 * * *$ \\
Innovation Intensity & $(0.0234)$ & $(0.0787)$ \\
\hline$* * * p \leq 0.01, * * p \leq 0.05, p \leq 0.10$. & Standard errors are reported under each coefficient in parentheses.
\end{tabular}




\section{Table 5}

\section{Female Representation in Top Management \& Firm Performance}

Endogeneity \& Reverse Causality

\begin{tabular}{|c|c|c|}
\hline & \multicolumn{2}{|c|}{ Tobin's Q } \\
\hline & 1: Fixed Effects OLS & 2: Arellano-Bond \\
\hline \multirow{2}{*}{ Tobin's Q $[t-1]$} & $0.4040 * * *$ & $0.3596 * * *$ \\
\hline & $(0.00062)$ & $(0.0107)$ \\
\hline \multirow[t]{2}{*}{ Innovation Intensity } & $-0.0610 *$ & 0.1081 \\
\hline & $(0.0362)$ & $(0.0813)$ \\
\hline \multirow[t]{2}{*}{ Size } & $-0.1029 * * *$ & $-0.1609 * * *$ \\
\hline & $(0.0032)$ & $(0.0077)$ \\
\hline \multirow[t]{2}{*}{ Firm Age } & $0.0077 * * *$ & $0.0583 * * *$ \\
\hline & $(0.0007)$ & $(0.0019)$ \\
\hline \multirow[t]{2}{*}{ Leverage } & -0.0018 & $0.0817 * * *$ \\
\hline & $(0.0077)$ & $(0.0127)$ \\
\hline \multirow[t]{2}{*}{ CapEx Intensity } & -0.0144 & $-0.4457 * * *$ \\
\hline & $(0.0285)$ & $(0.0721)$ \\
\hline \multirow[t]{2}{*}{ Marketing Intensity } & $-0.1538 * *$ & $-0.7068 * * *$ \\
\hline & $(0.0770)$ & $(0.1738)$ \\
\hline \multirow[t]{2}{*}{ Age of Capital Stock } & $-0.1423 * * *$ & $-0.0979 * * *$ \\
\hline & $(0.0133)$ & $(0.0183)$ \\
\hline \multirow[t]{2}{*}{ Number of Managers } & $-0.0037 * * *$ & -0.0026 \\
\hline & $(0.0013)$ & $(0.0028)$ \\
\hline \multirow[t]{2}{*}{ Female Representation } & -0.0017 & 0.0181 \\
\hline & $(0.0053)$ & $(0.0144)$ \\
\hline \multirow[t]{2}{*}{ Female Representation $x$ Innovation Intensity } & $0.2172 * * *$ & $0.3269 * * *$ \\
\hline & $(0.0549)$ & $(0.1089)$ \\
\hline
\end{tabular}

*** $p \leq 0.01, * * p \leq 0.05, p \leq 0.10$. Standard errors are reported under each coefficient in parentheses. 